\title{
EFFECT OF INDIVIDUAL FINGER SKIN TEMPERATURE ON VIBROTACTILE PERCEPTION THRESHOLD
}

\author{
BARBARA HARAZIN ${ }^{1,2}$, AGNIESZKA HARAZIN-LECHOWSKA ${ }^{3}$, and JACEK KAŁAMARZ ${ }^{4}$ \\ ${ }^{1}$ Institute of Occupational Medicine and Environmental Health, Sosnowiec, Poland \\ Ward for Occupational Diseases \\ ${ }^{2}$ The School of Higher Vocational Education, Nysa, Poland \\ ${ }^{3}$ Maria Skłodowska-Curie Institute, Kraków, Poland \\ Department of Tumour Pathology, Oncology Centre \\ ${ }^{4}$ Luxmed Group Medical Center, Katowice, Poland
}

\begin{abstract}
Objectives: In healthy people, the vibrotactile perception threshold (VPT) at fingertips depends on a given measurement method and on individual characteristics such as age, gender and finger skin temperature. The aim of the study was to compare the VPT values in 2 groups of healthy subjects with different finger skin temperature. Materials and Methods: The study group comprised 56 males and 76 females, who formed pairs matched with respect to age, gender and body mass index (BMI) but differing in terms of finger skin temperature at pre-launch testing. The finger skin temperature of less than $29^{\circ} \mathrm{C}$ indicated the subjects with "cold hands" and that of more than $29^{\circ} \mathrm{C}$, the subjects with "warm hands". The measuring system made use of P8 pallesthesiometer (EMSON-MAT, Poland) and the measurement procedure was in compliance with the ISO 13091-1:2001 standard. VPT measurements were performed for the index, middle and ring fingers of both hands at the frequencies of $4 \mathrm{~Hz}, 25 \mathrm{~Hz}, 31.5 \mathrm{~Hz}, 63 \mathrm{~Hz}, 125 \mathrm{~Hz}$ and $250 \mathrm{~Hz}$. Results: The findings of the study revealed that the mean VPTs among the subjects with "cold hands" were significantly higher than the corresponding values among the subjects with "warm hands". Conclusions: The type of individual peripheral thermoregulation should be considered when assessing the VPT and determining its reference values.
\end{abstract}

Key words:

Vibrotactile perception threshold, Finger skin temperature, Women, Men

\section{INTRODUCTION}

Early detection of peripheral neuropathies is beneficial in the diagnostics and prevention of occupational diseases resulting from exposure to health hazards at work. For a quantitative assessment of peripheral nervous system disorders, the vibrotactile perception threshold (VPT) at fingertips is measured using pallesthesiometry.

Impaired vibrotactile perception may be induced by some exogenic factors including neurotoxic chemicals, a number of anticancer drugs and physical factors having direct impact on upper extremities, namely cumulated mechanical trauma and vibration [1,2]. It may also be caused by such conditions as diabetic, alcohol-related, hormonal, metabolic and inflammatory mononeuropathies, carpal tunnel syndrome as well as malnutritionrelated polyneuropathies [3]. The vibrotactile perception depends on many factors connected with the characteristics of vibration stimulus, a psychophysical measurement

Received: January 16, 2013. Accpted: October 10, 2013.

Corresponding author: B. Harazin, Institute of Occupational Medicine and Environmental Health, Ward for Occupational Diseases, Kościelna 13, 41-200 Sosnowiec, Poland (e-mail: b.harazin@imp.sosnowiec.pl) 
procedure in which the stimulus is used to determine thresholds, experimental conditions and individual features of subjects [4,5].

The use of vibrotactile perception measurements as a method for diagnosing early disorders of the peripheral nervous system within upper extremities, which occur e.g. in the hand-arm vibration syndrome, made it necessary to standardize the methods used for measurements and results interpretation of VPT at fingertips. This task, undertaken by the International Organization for Standardization, has brought about the development of the ISO 13091-1 and 13091-2 standards in 2001 and 2003, respectively [6,7]. The contained therein methodological requirements may be used to determine reference values for VPT at fingertips measured under predefined conditions for the 3 following mechanoreceptors: SAI Merkel discs, FAI - Meissner corpuscles, and FAII - Pacinian corpuscles which mediate perception over a given frequency range.

However, a number of important factors that have considerable impact on vibration perception should be verified beforehand. These include individual features of subjects, such as age, gender, anthropometric data and finger skin temperature [8,9]. According to the ISO 13091-1 standard, it is assumed that the VPTs for the SAI, FAI and FAII receptors are not significantly dependent on finger skin temperature within the range of $27-35^{\circ} \mathrm{C}$. Literature data indicate that vibration perception declines along with the decreasing finger skin temperature under experimental conditions of cooling the subject's hands in cold water or with cool air [10-12]. However, the influence of individual finger skin temperature on VPT has not been elucidated thus far.

The present study aimed at investigating whether there are any differences in VPT, determined in accordance with ISO 13091-1 standard, between healthy males and females of the same age and similar BMI but with a different finger skin temperature.

\section{MATERIAL AND METHODS}

\section{Subjects}

One hundred and thirty two healthy individuals, aged 1966 years took part in the study. They represented different professions and were not occupationally exposed to vibration. The subjects were enrolled in the study based on internal and neurological histories and selected upper extremity examinations for limited mobility of wrist joints, presence of contractures, scars and thickening of the epidermis. The exclusion criteria included:

- diseases leading to peripheral neuropathies, such as hyper- or hypothyroidism, diabetes mellitus, neck pain and alcoholism;

- pharmacotherapy with drugs toxic to the peripheral nervous system;

- reporting muscle pain or weakness, and tingling and numbness within upper extremities.

Of all the 390 subjects classified for the study, 56 males, aged 19-66 years, and 76 females, aged 19-50 years, were selected, and pairs of subjects matched for age, gender and BMI were formed. In the female group, the mean age difference between the subjects in each pair, calculated for the whole group, was $0.84 \pm 0.81$ year, while in the male group, the respective value was $0.93 \pm 0.77$ year. The mean BMI difference between the pairs of subjects was $1.17 \pm 1.15 \mathrm{~kg} / \mathrm{m}^{2}$ among females and $1.52 \pm 1.08 \mathrm{~kg} / \mathrm{m}^{2}$ among males.

The persons in each pair differed only with respect to the mean finger skin temperature, which was either higher or lower than $29^{\circ} \mathrm{C}$. The subjects were classified into the group "with cold hands" when they reported having usually cold hands and being oversensitive to cold. In these subjects, the finger skin temperature did not exceed $29^{\circ} \mathrm{C}$ even though they were staying in a room in which the air temperature was not lower than $21^{\circ} \mathrm{C}$.

All the subjects gave their written informed consent to participate in the study. They did not receive any remuneration for taking part in the project. Table 1 summarizes 
Table 1. Characteristics of the subjects with cold $\left(<29^{\circ} \mathrm{C}\right)$ and warm $\left(>29^{\circ} \mathrm{C}\right)$ hands

\begin{tabular}{|c|c|c|c|c|}
\hline \multirow[t]{2}{*}{ Variables } & \multicolumn{2}{|c|}{$\begin{array}{c}\text { Men } \\
(\mathrm{N}=56) \\
\mathrm{M} \pm \mathrm{SD} \text { (range) }\end{array}$} & \multicolumn{2}{|c|}{$\begin{array}{c}\text { Women } \\
(\mathrm{N}=76) \\
\mathrm{M} \pm \mathrm{SD} \text { (range) }\end{array}$} \\
\hline & $\begin{array}{l}\text { cold hands } \\
(\mathrm{N}=28)\end{array}$ & $\begin{array}{c}\text { warm hands } \\
(\mathrm{N}=28)\end{array}$ & $\begin{array}{l}\text { cold hands } \\
(\mathrm{N}=38)\end{array}$ & $\begin{array}{c}\text { warm hands } \\
(\mathrm{N}=38)\end{array}$ \\
\hline Age (years) & $\begin{array}{c}37.9 \pm 15.8 \\
(19-66)\end{array}$ & $\begin{array}{c}38.5 \pm 14.6 \\
(19-66)\end{array}$ & $\begin{array}{c}30.7 \pm 12.8 \\
(19-50)\end{array}$ & $\begin{array}{c}30.6 \pm 12.6 \\
(19-50)\end{array}$ \\
\hline Body Mass Index & $\begin{array}{c}25.8 \pm 3.6 \\
(18.6-32.7)\end{array}$ & $\begin{array}{c}25.7 \pm 3.0 \\
(20.4-30,8)\end{array}$ & $\begin{array}{c}22.2 \pm 3.4 \\
(18.9-31.5)\end{array}$ & $\begin{array}{c}22.4 \pm 3.4 \\
(18.1-33.3)\end{array}$ \\
\hline \multicolumn{5}{|c|}{ Finger skin temperature $\left({ }^{\circ} \mathrm{C}\right)$} \\
\hline left hand & $\begin{array}{c}27.8 \pm 1.2 \\
(23.9-28.9)\end{array}$ & $\begin{array}{c}31.5 \pm 1.0 \\
(29.6-33.4)\end{array}$ & $\begin{array}{c}25.4 \pm 1.6 \\
(22.5-28.5)\end{array}$ & $\begin{array}{c}31.0 \pm 1.5 \\
(29.1-34.3)\end{array}$ \\
\hline right hand & $\begin{array}{c}27.9 \pm 1.2 \\
(24.5-28.6)\end{array}$ & $\begin{array}{c}31.6 \pm 1.2 \\
(29.0-33.4)\end{array}$ & $\begin{array}{c}25.8 \pm 1.7 \\
(22.2-28.9)\end{array}$ & $\begin{array}{c}31.2 \pm 1.5 \\
(29.0-34.1)\end{array}$ \\
\hline
\end{tabular}

M - mean; SD - standard deviation.

the subjects' characteristics and their mean finger skin temperature.

\section{Measuring system}

VPT was measured using P8 pallesthesiometer (EMSONMAT, Poland). The measuring system consisted of a vibrometer unit with a stimulating probe, a subject response button, and the vibrometer software. The stimulating probe was a flat-ended perspex cylinder, $5 \mathrm{~mm}$ in diameter.

The subject kept his/her forearm and hand on the unit box, resting the palm on a special support that ensured contact between the fingertip and the probe, and pressed the stimulating probe in such a way that the finger would not touch the surface surrounding the probe (according to ISO 13091-1, Method A: without surround) [6]. Vibration was applied to the distal phalanx at the site located halfway between the centre of the whorl and the fingernail. The subject pressed the probe and watched the control panel for 2 small lights going on and off. When the pressure was too strong or too weak, one of the lamps lit up. The lamp went out if the predefined static force of $0.1 \mathrm{~N}$ was achieved. The procedure makes the subject monitor the pressing force and maintain it at the right level.
VPT was determined using von Bèkèsy algorithm in which continuous sinusoidal stimulus with time-varying amplitude in root mean square (r.m.s.) acceleration level is used to determine sequentially ascending and descending thresholds. Based on these principles, in our experiment, the vibration magnitude was increasing until the subject perceived the vibration and pressed the response button held in the other hand. Then the vibration was decreasing until the subject could no longer perceive the vibration stimulus and released the button. A continuous vibration stimulus was applied and its magnitude increased and decreased at a constant rate of $2 \mathrm{~dB} / \mathrm{s}$.

\section{Experimental procedure}

Prior to the experiment, each subject practiced the testing task in order to familiarize with the vibration stimuli and the measurement procedure. They received standard oral instructions.

Initially, VPTs were determined for the index finger of the right hand for the 3 following frequencies: $4 \mathrm{~Hz}, 25 \mathrm{~Hz}$ and $125 \mathrm{~Hz}$. According to the ISO 13091-1 standard, background vibration was measured prior to each measurement session, using a stimulating probe in contact with 
finger skin, as well as when no stimulus was applied. It was measured at sufficient bandwidth and was lower than the VPT at the frequency for which the threshold was calculated [6]. The practice took about 3-4 min and each subject received the same amount of training.

VPT measurements were performed for the index, middle and ring fingers of both hands at the following frequencies: $4 \mathrm{~Hz}, 25 \mathrm{~Hz}, 31.5 \mathrm{~Hz}, 63 \mathrm{~Hz}, 125 \mathrm{~Hz}$ and $250 \mathrm{~Hz}$. According to the ISO 13091-1 standard, the vibration frequency range used for testing applied to the 3 mechanoreceptors: SAI - Merkel cell, FAI - Meissner corpuscles, and FAII - Pacinian corpuscles. In the present study, this range was extended by adding the $250 \mathrm{~Hz}$ frequency for a more detailed assessment of the impact of finger skin temperature on VPT.

The finger skin temperature at distal phalanx in the 3 fingers of both hands was measured before and after VPT assessment. The measurements were made with $\pm 0.1^{\circ} \mathrm{C}$ precision, using a non-contact infrared thermometer (FR 260 MV, Ahlborn, Germany). Each measuring session lasted not more than $30 \mathrm{~min}$.

Smoking and drinking beverages containing caffeine was not allowed for at least $1 \mathrm{~h}$ prior to the experiment. The subjects, who reported having an antibiotic therapy in the past, were allowed to participate if their therapy finished at least 2 weeks before the onset of the study.

The room temperature was between $21^{\circ} \mathrm{C}$ and $25^{\circ} \mathrm{C}$ (mean $22.9 \pm 1^{\circ} \mathrm{C}$ ) and noise level was lower than $50 \mathrm{~dB}-\mathrm{A}$. All the measurements were performed by the same person $(\mathrm{BH})$. No outsiders were allowed to enter the laboratory during testing.

\section{STATISTICAL ANALYSIS}

Two-way analysis of variance (ANOVA) with repeated measures was used to assess the effects of vibration frequency $(4 \mathrm{~Hz}, 25 \mathrm{~Hz} 31.5 \mathrm{~Hz}, 63 \mathrm{~Hz}, 125 \mathrm{~Hz}$ and $250 \mathrm{~Hz}$ ) and the low or high finger skin temperature $\left(<29^{\circ} \mathrm{C}\right.$ and $>29^{\circ} \mathrm{C}$, respectively) on VPT. The subject's VPT was determined as the mean threshold for 6 fingers. The mean VPT values were calculated for all the subjects from one group for a given vibration frequency. The paired t-test was used to compare the effect of finger skin temperature in 2 groups of subjects on VPT at each vibration frequency. Tukey test was used in post-hoc analysis to assess the significance of differences between the mean VPT determined for all the 6 frequencies $(4 \mathrm{~Hz}, 25 \mathrm{~Hz} 31.5 \mathrm{~Hz}, 63 \mathrm{~Hz}$, $125 \mathrm{~Hz}$ and $250 \mathrm{~Hz}$ ) in the 2 groups of the subjects with different finger skin temperature $\left(<29^{\circ} \mathrm{C}\right.$ and $\left.>29^{\circ} \mathrm{C}\right)$. Statistical analysis was performed using the Statistical Package for Statistica 10.1, StatSoft Poland.

\section{RESULTS}

Figures 1 and 2 show the differences in VPTs between the subjects with normal finger skin temperature (mean: $>31^{\circ} \mathrm{C}$ ) and decreased finger skin temperature (mean: $<27.9^{\circ} \mathrm{C}$ in males and $<25.9^{\circ} \mathrm{C}$ in females).

The two-way analysis of variance revealed a significant influence of vibration frequency on VPT, both among males $\left(\mathrm{F}_{(5,1002)}=501.9, \mathrm{p}<0.0001\right)$ and females $\left(\mathrm{F}_{(5,1362)}=362.8\right.$, $\mathrm{p}<0.0001)$. Belonging to the group with low or high finger

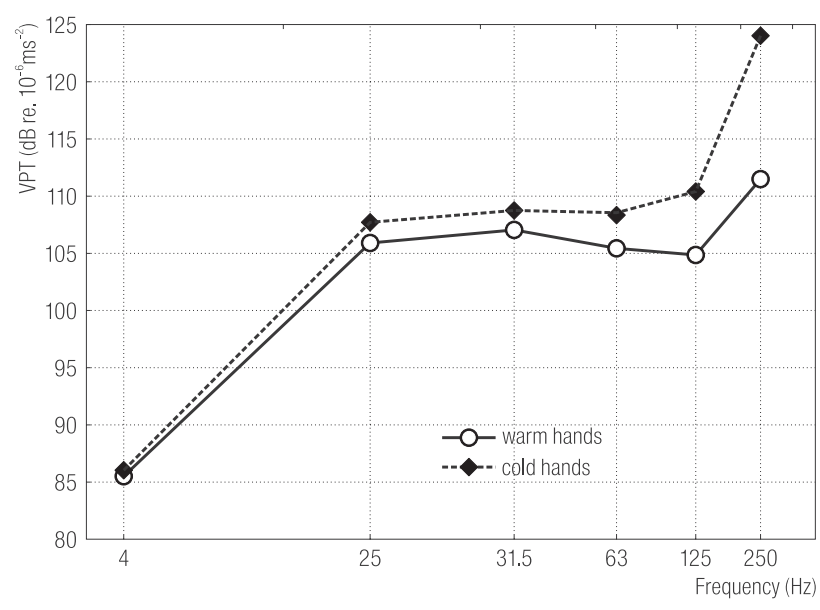

Fig. 1. Comparison of the mean vibrotactile perception thresholds (VPT) between the women with warm $\left(>29^{\circ} \mathrm{C}\right)$ and cold hands $\left(<29^{\circ} \mathrm{C}\right)$ 


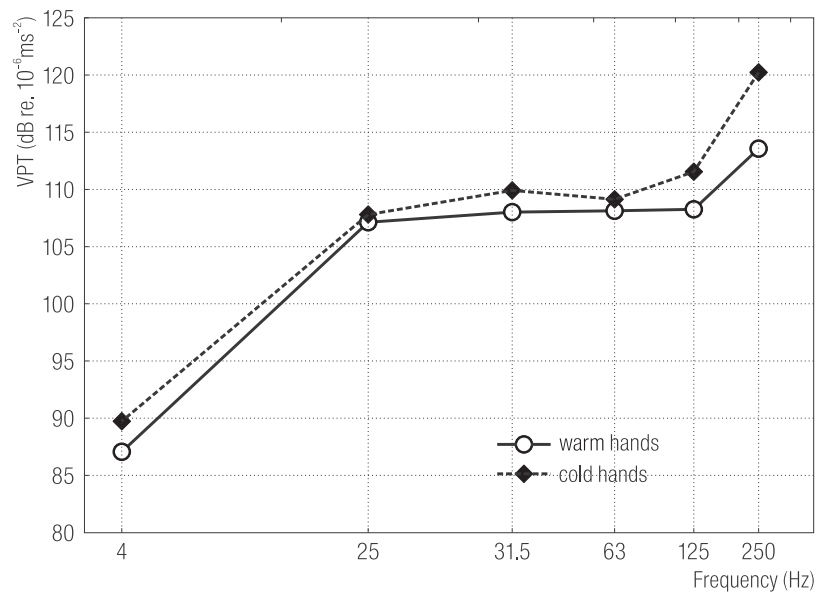

Fig. 2. Comparison of the mean vibrotactile perception thresholds (VPT) between the men with warm $\left(>29^{\circ} \mathrm{C}\right)$ and cold hands $\left(<29^{\circ} \mathrm{C}\right)$

skin temperature was also found to be a significant factor having influence on the VPT value, both among males $\left(\mathrm{F}_{(1,1002)}=74, \mathrm{p}<0.0001\right)$ and females $\left(\mathrm{F}_{(1,1362)}=16\right.$, $\mathrm{p}<0.0001)$. Interaction between a given subgroup (subjects with cold or warm hands) and stimulation frequency were statistically significant for males $\left(\mathrm{F}_{(5,1002)}=8\right.$, $\mathrm{p}<0.0001)$ and females $\left(\mathrm{F}_{(5,1362)}=8.8, \mathrm{p}<0.0001\right)$, indicating that the effect of finger skin temperature on VPT strongly depended on stimulation frequency.

The mean VPTs were significantly lower among females with warm hands than among those with cold hands for vibration frequencies ranging from $25 \mathrm{~Hz}$ to $250 \mathrm{~Hz}$ (the paired t-test; $p<0.05)$. The largest and most significant differences in VPTs could be found at the following frequencies: $63 \mathrm{~Hz}, 125 \mathrm{~Hz}, 250 \mathrm{~Hz}$ (the paired t-test; $\mathrm{p}<0.0001$ ) (Table 2). There were no between-group differences in VPT at the frequency of $4 \mathrm{~Hz}$. In the male group, lower VPTs referred to the subjects with warm hands rather than to those with cold hands. However, the differences were not as high as in the female group and were not observed for all the frequencies under study. The highest VPT differences could be noted at $125 \mathrm{~Hz}$ and $250 \mathrm{~Hz}$ (the paired t-test; $\mathrm{p}<0.001$ and $\mathrm{p}<0.0001$, respectively). No significant differences were found for the low frequencies of $4 \mathrm{~Hz}$ and $25 \mathrm{~Hz}$ as well as for $63 \mathrm{~Hz}$. At high frequencies of $125 \mathrm{~Hz}$ and $250 \mathrm{~Hz}$, the VPT differences between the female subgroups were almost twice as high as those between the male subgroups.

Table 2. Differences in vibrotactile perception thresholds (VPT) between the subjects with cold and warm hands, expressed as the function of vibration frequency ${ }^{1}$

\begin{tabular}{|c|c|c|c|c|c|c|}
\hline \multirow{3}{*}{$\begin{array}{l}\text { Frequency } \\
\quad(\mathrm{Hz})\end{array}$} & \multicolumn{4}{|c|}{$\begin{array}{l}\text { Thresholds ( } \mathrm{dB} \text { re. } 10^{-6} \mathrm{~ms}^{-2} \text { ) } \\
\qquad \mathrm{M} \pm \mathrm{SD}\end{array}$} & \multirow{2}{*}{\multicolumn{2}{|c|}{$\begin{array}{l}\text { Difference in VPT between the } \\
\text { subjects with cold and warm hands } \\
\qquad \mathrm{M}(\mathrm{dB})\end{array}$}} \\
\hline & \multicolumn{2}{|c|}{ women } & \multicolumn{2}{|c|}{ men } & & \\
\hline & warm hand & cold hand & warm hand & cold hand & women & men \\
\hline 4 & $85.5 \pm 5.7$ & $86.0 \pm 5.3$ & $87.1 \pm 4.3$ & $88.3 \pm 5.0$ & 0.5 & 1.2 \\
\hline 25 & $105.9 \pm 5.9$ & $107.7 \pm 5.7$ & $107.1 \pm 6.3$ & $107.8 \pm 7.7$ & $1.8^{* *}$ & 0.7 \\
\hline 31.5 & $107.1 \pm 6.1$ & $108.8 \pm 5.9$ & $108.1 \pm 6.6$ & $109.9 \pm 6.9$ & $1.7^{*}$ & $1.9^{*}$ \\
\hline 63 & $105.5 \pm 6.8$ & $108.3 \pm 7.0$ & $108.1 \pm 7.1$ & $109.1 \pm 7.6$ & $2.9^{* * *}$ & 1.0 \\
\hline 125 & $104.9 \pm 6.3$ & $110.4 \pm 7.7$ & $108.3 \pm 7.6$ & $111.5 \pm 10.0$ & $5.6^{* * * *}$ & $3.3^{* *}$ \\
\hline 250 & $111.5 \pm 6.2$ & $124.0 \pm 8.4$ & $113.6 \pm 8.1$ & $120.2 \pm 10.1$ & $12.5^{* * *}$ & $6.7 * * *$ \\
\hline
\end{tabular}

${ }^{1}$ Statistical significance of the differences between mean values in VPT between the subjects with cold and warm hands was tested using the paired t-test.

$\mathrm{M}-$ mean.

$* \mathrm{p}<0.05$.

** $\mathrm{p}<0.001$.

$* * * \mathrm{p}<0.0001$. 
The course of the VPT curve plotted for the persons with low finger skin temperature ("cold hands") was different from that for the persons with high skin temperature of the fingers ("warm hands"). In the female group, more distinct VPT differences between the subgroups were recorded for vibration frequencies starting from $63 \mathrm{~Hz}$. As regards the subgroup with warm hands, no VPT differences were noted for vibration frequencies of $125 \mathrm{~Hz}$ and $63 \mathrm{~Hz}$ (Tukey test; $p=0.9201)$. In the subgroup with cold hands, VPT was significantly higher for the vibration frequency of $125 \mathrm{~Hz}$ than for that of $63 \mathrm{~Hz}$ (Tukey test; $\mathrm{p}=0.018$ ).

The male subgroup of the subjects with warm hands presented no significant VPT differences for the frequency range of $25-125 \mathrm{~Hz}$, with the plateau covering 4 frequencies: $25 \mathrm{~Hz}, 31.5 \mathrm{~Hz}, 63 \mathrm{~Hz}$ and $125 \mathrm{~Hz}$ (Tukey test; $\mathrm{p}>0.6$ ). Among the subjects with cold hands, the plateau covered only 3 frequencies: $25 \mathrm{~Hz}, 31.5 \mathrm{~Hz}$ and $63 \mathrm{~Hz}$; however, at $125 \mathrm{~Hz}$, the VPT value slightly increased as compared to that noted at $63 \mathrm{~Hz}$ (Tukey test; $\mathrm{p}=0.067$ ).

The observed gender-related difference in the course of the VPT curve may be due to the fact that the mean finger skin temperature in the female subjects with cold hands was lower by $2^{\circ} \mathrm{C}$ than in the respective male subgroup. Furthermore, the group of male subjects was generally older than the female group (Table 1).

\section{DISCUSSION}

The studies regarding the influence of finger skin temperature on VPT are based on 2 models of peripheral thermoregulation:

- a short-term maintenance of the skin temperature by cooling or warming hands under experimental conditions;

- natural individual differentiation of the skin temperature of the fingers.

The first model addresses the problem of how the changes in external physical environment, in this case temperature, can affect the perception of vibration stimulus. The other model is used to investigate the possible influence that finger skin temperature, associated with systemic neurophysiological processes, can have on VPT. The so far conducted studies have focused mostly on a quantitative assessment of changes in VPT due to the cooling or warming of hands. Literature data indicate that when the finger skin temperature decreases within the range from $32^{\circ} \mathrm{C}$ to $20^{\circ} \mathrm{C}$ [13], the VPT mediated by Pacinian corpuscles increases from $5 \mathrm{~dB}$ to $7 \mathrm{~dB}$ at vibration frequency of $125 \mathrm{~Hz}$, and up to $12 \mathrm{~dB}$ at $250 \mathrm{~Hz}$.

However, further hands warming to the temperatures higher than $33^{\circ} \mathrm{C}$ produce a slight (ca. 2-3 dB) but significant increase in VPT as compared to normal levels [14-17]. One can thus assume that a short-term overheating of hands may lead to the impaired perception of the vibration stimulus.

The opinions vary with respect to the level of finger skin temperature that could be used as a reference value for VPT determination. So far, no value has been proposed for boundary temperature that would derive from assessment of the impact of individual finger skin temperature on VPT. Referring to the findings published by Verrillo and Bolanowski [13] and by Green [15], Lundström et al. postulate that "A skin temperature lower than $28^{\circ} \mathrm{C}$ should be avoided" [18]. In both studies, the subjects had their finger skin temperature raised or lowered by heating or cooling their hands. Klinenberg et al. considering the experimental findings for changes in finger skin temperature, presumed that the "finger skin temperature should be maintained above $29^{\circ} \mathrm{C}$ during the measurement" [19]. In VPT assessments for workers exposed to hand-arm vibration, diverse finger skin temperatures $\left(28-33^{\circ} \mathrm{C}\right)$ were achieved, mainly by warming hands in water bath or using heat lamps [20,21].

When assessing the impact of finger skin temperature on VPT, one should consider the 3 following types of peripheral thermoregulation in an individual [22]: 
- homoiotherm, when the finger skin temperature ranges from $27^{\circ} \mathrm{C}$ to $34^{\circ} \mathrm{C}$ (mean: $31^{\circ} \mathrm{C}$ );

- poikilotherm, for low levels of finger skin temperature $\left(18-27^{\circ} \mathrm{C}\right)$;

- amphitherm, being a combination of the 2 other types, with alternating variation of finger skin temperatures characteristic for homoiothermics and poikilothermics.

In this study we recognized that low finger skin temperature is more common among young women than among young men. The proportion of the young male subjects with cold hands did not correspond to the proportion of the respective young female subjects. This was so, even though each group of the subjects classified for the study within the age range of up to 35 years comprised over 60 subjects.

The present study results have also supported the finding (Table 1). Of the total 190 male subjects, no one presented as a low mean finger skin temperature as the one in the female group (both populations were of a similar size: male $(\mathrm{N}=190)$ and female $(\mathrm{N}=200)$, and had a similar male to female ratio in each age group).

In the male group, the difference in VPT for the subjects with cold and warm hands amounted to $1 \mathrm{~dB}$ at $6 \mathrm{~Hz}$ for the mean difference in finger skin temperature of $3.7^{\circ} \mathrm{C}$. Therefore, this difference was too low to produce a statistically significant difference in VPT at $63 \mathrm{~Hz}$. Among the females, the mean difference in finger skin temperature between the 2 groups was higher and approximated $5.6^{\circ} \mathrm{C}$. This higher value had an impact on VPT at $63 \mathrm{~Hz}$ and produced a difference of $2.9 \mathrm{~dB}$ between the 2 groups. It would be interesting to find what the limit value of the difference in finger skin temperature at $63 \mathrm{~Hz}$ that would induce a significant effect on VPT should be. As revealed by the studies conducted by Bolanowski et al. [23] and Gescheider et al. [24] there is no evident boundary between vibration perception by the Meissner corpuscles or the Pacinian corpuscles. Accordingly, it is only at the frequency of $125 \mathrm{~Hz}$ that induces the highest perception sensitivity of the Pacinian corpuscles, that the influence of finger skin temperature on VPT can be clearly seen.

In accordance with the ISO 13091-1 standard, in VPT studies, the finger skin temperature of the subjects should vary between $27^{\circ} \mathrm{C}$ and $35^{\circ} \mathrm{C}$. In other words, these requirements apply only to the subjects with homoiotherm peripheral thermoregulation [6]. It seems that the ISO standard adopts $27^{\circ} \mathrm{C}$ as the lower limit value for finger skin temperature and, therefore, it does not provide any guidelines regarding persons with lower levels of this parameter.

The few studies on VPT that have been conducted so far, have not revealed any significant influence of finger skin temperature on VPT. Whitehouse et al. report negative but not statistically significant correlations between finger skin temperatures and VPTs determined at the frequencies ranging from 8 to $250 \mathrm{~Hz}$ in 14 male subjects with the mean finger skin temperature of $32.8^{\circ} \mathrm{C}$ (range: $24.7-$ $\left.35.5^{\circ} \mathrm{C}\right)$ [25]. Likewise, Maurissen and Chrzan did not obtain significant findings in their studies on VPTs measured at $150 \mathrm{~Hz}$ in 29 women with finger skin temperature ranging from $23.6^{\circ} \mathrm{C}$ to $35.3^{\circ} \mathrm{C}$ (mean: $34^{\circ} \mathrm{C}$ ) [26]. Researchers investigating the possible influence of skin temperature on VPT among healthy subjects should consider a number of individual characteristics such as age, gender and BMI, that can affect the study results [27-29].

The presence of 2 different individual features in a given study group may bring about a diverse impact on VPT. One of the factors may increase VPT in some subjects, e.g. age-related impairment in perception, and other factor may decrease VPT in other subjects, e.g. improved vibration perception with temperature increase. Thus, it may happen that young people with cold hands will have higher VPTs than older people with warm hands. Therefore, in our comparative studies, we have distinguished pairs of subjects who differed only with respect to finger skin temperature, which led to elimination of the other modifiers, i.e. age, gender, and BMI. 
The results of our studies do not support the findings of other authors who claim that at stimulation frequencies of less than $200 \mathrm{~Hz}$, the VPTs for FAII receptors are not significantly dependent on skin temperature [30]. We found that among the subjects with low mean skin temperature of $25.4^{\circ} \mathrm{C}$, the influence of this parameter on VPT at stimulation frequencies of $125 \mathrm{~Hz}$ and $250 \mathrm{~Hz}$ was of the same order of magnitude as in the experimental studies with the subjects having their finger skin temperature changed by warming or cooling within the range of $20-30^{\circ} \mathrm{C}$.

It should be stressed that the experimental studies aimed at defining the range of changes in vibration perception by particular mechanoreceptors mainly as a result of local variations in finger skin temperature. However, in medical diagnostics, the dysfunction of a given system is often assessed under conditions of pressure and increased effort in order to check the system efficiency when facing particularly stressful conditions. This refers, for instance, to the assessment of recovery time in peripheral vascular disorders within upper extremities in a cold provocation test or, to the determination of blood glucose curve in diabetics. A question then arises: why in pallesthesiometry used for diagnostics of the peripheral nervous system, are the functions of finger mechanoreceptors locally improved by warming hands to a predefined temperature level? In workers, low finger skin temperature may be related to the impact of various occupational hazards on the peripheral cardiovascular system, e.g. the exposure to hand-arm vibration [31,32]. Therefore, experimental finger skin warming up may blur or distort the testing results in workers examined for the function of the peripheral nervous system. It would be necessary to define testing conditions based on microclimatic parameters of the testing facilities and on the expected period of adaptation to these conditions. Such an approach would be more reasonable than the models based on short-term maintenance of skin temperature that does not always comply with the actual individual characteristics and health condition of the examined person.

\section{CONCLUSIONS}

When assessing the VPT and determining its reference values the type of individual peripheral thermoregulation should be taken into account. Future studies on VPT should address the problem of a short-term warming of hands in people with peripheral nervous system dysfunctions and its evidence-based justification for use.

\section{REFERENCES}

1. Gerr F, Hershman D, Letz R. Vibrotactile threshold measurement for detecting neurotoxity: Reliability and determination of age and height - standardised normative values. Arch Environ Health. 1990;45:148-54.

2. Torgen M, Swerup C. Individual factors and physical work load in relation to sensory thresholds in a middle-aged general population sample. Eur J Appl Physiol. 2002;86: 428-37.

3. Juntunen J, Haltia M. Polyneuropathies in occupational neurology: Pathogenetic and clinical aspects. Acta Neurol Scand. 1982;66(Suppl): 59-73.

4. Harada N, Griffin MJ. Factors influencing vibration sense thresholds used to assess occupational exposures to hand transmitted vibration. Br J Ind Med. 1991;48:185-92, http:// dx.doi.org/10.1136/oem.48.3.185.

5. Lindsell Ch, Griffin MJ. A standardised test battery for assessing vascular and neurological components of the handarm vibration syndrome. In: Lundstrom R, Lindmark A, editors. Eighth International Conference on Hand-Arm Vibration 9-12 June 1998, Umea, Sweden. Stockholm: National Institute for Working Life; 2000. p. 133-41.

6. ISO 13091-1. Mechanical vibration - Vibrotactile perception thresholds for the assessment of nerve dysfunction - Part 1: Method of measurement at the fingertips. Geneva: International Organization for Standardization; 2001.

7. ISO 13091-2. International Organization for Standardization. Mechanical vibration - Vibrotactile perception thresholds for the assessment of nerve dysfunction - Part 2: Analysis and 
interpretation of measurements at the fingertips. Geneva: International Organization for Standardization; 2003.

8. Skov T, Steenland K, Deddens J. Effect of age and height on vibrotactile threshold among 1,663 U.S. workers. Am J Ind Med. 1998;34(5):438-44, http://dx. doi.org/10.1002/(SICI)1097-0274(199811)34:5<438::AIDAJIM4>3.3.CO;2-3.

9. Wiles PG, Pearce SM, Rice PJS, Mitchell JMO. Vibration perception threshold: influence of age, height, sex, and smoking, and calculation of accurate percentile values. Diab Med. 1991;8:157-61.

10. Bolanowski SJ, Verrillo RT. Temperature and criterion effects in a somatosensory subsystem: a neurophysiological and psychophysical study. J Neurophysiol. 1982;48(3): $836-55$.

11. Halonen P. Quantitative vibration perception thresholds in healthy subjects of working age. Eur J Appl Physiol. 1986;54:647-55, http://dx.doi.org/10.1007/BF00943355.

12. Harada N, Nakamoto A, Takaoka K. Factors influencing vibration sense thresholds test and somatosensory evoked responses to electrical stimulation as an objective test. In: Gemne G, Brammer AJ, Hagberg M, Lundström R, Nilsson T, editors. Stockholm Workshop 94. Hand-arm vibration syndrome: diagnostics and quantitative relationships to exposure. National Institute of Occupational Health, Solna, Sweden. Arbete Hälsa, 1995;5:65-71.

13. . Verrillo RT, Bolanowski SJ. The effects of skin temperature on the psychophysical responses to vibration on glabrous and hairy skin. J Acoust Soc Am. 1986;80(2):528-32.

14. Gescheider GA, Thorpe JM, Goodarz J, Bolanowski SJ. The effects of skin temperature on the detection and discrimination of tactile stimulation. Somatosens Motor Res. 1997;14:181-8.

15. Green BG. The effect of skin temperature on vibrotactile sensitivity. Percept Psychophys. 1977;21:243-8, http://dx.doi. org/10.3758/BF03214234.

16. Harazin B, Harazin-Lechowska A. Effect of changes in finger skin temperature on vibrotactile perception threshold.
Int J Occup Med Environ Health. 2007;20(3):223-7, http:// dx.doi.org/10.2478/v10001-007-0027-z.

17. Weitz J. Vibratory sensitivity as a function of skin temperature. J Exp Psychol. 1941;28(1):21-36, http://dx.doi. org/10.1037/h0059426.

18. Lundström R, Strömberg T, Lundborg G. Vibrotactile perception threshold measurements for diagnosis of sensory neuropathy. Int Arch Occup Environ Health. 1992;64(3): 201-7, http://dx.doi.org/10.1007/BF00380910.

19. Klinenberg E, So Y, Rempel D. Temperature effect on vibrotactile sensitivity threshold measurements: implications for carpal tunnel screening tests. J Hand Surg. 1996;21(1): 132-7, http://dx.doi.org/10.1016/S0363-5023(96)80166-3.

20. Ekenvall L, Nilsson BY, Gustavsson P. Temperature and vibration thresholds in vibration syndrome. $\mathrm{Br} \mathrm{J}$ Ind Med. 1986;43:825-9, http://dx.doi.org/10.1136/oem.43. 12.825 .

21. Virokannas H, Virokannas A. Temperature and vibration perception thresholds in workers exposed to hand-arm vibration. Centr Eur J Publ Health. 1995;3(Suppl):66-69.

22. Gahlen W, Klüken N. Über Variation, Norm und Labilität der Hauttemperatur. Klin Wohenschr. 1953;31(31/32): 754-8, http://dx.doi.org/10.1007/BF01682788. German.

23. Bolanowski SJ, Gescheider GA, Verrillo RT, Checkosky CM. Four channels mediate the mechanical aspects of touch. J Acoust Soc Am. 1988;84(5):1680-94, http://dx.doi. org/10.1121/1.397184.

24. Gescheider GA, Bolanowski SJ, Pope J, Verrillo RT. A four-channel analysis of the tactile of the fingertip: frequency selectivity, spatial summation, and temporal summation. Somatosens. Res. 2002;19(2):114-24, http://dx.doi. org/10.1080/08990220220131505.

25. Whitehouse DJ, Morioka M, Griffin MJ. Effect of contact location on vibrotactile thresholds at fingertip. Somatosens Mot Res. 2006;23(1-2):73-81, http://dx.doi. org/10.1080/08990220600741119.

26. Maurissen JPJ, Chrzan GJ. One-year reliability of vibration sensitivity thresholds in human beings. J Neurol 
Sci. 1989;90(3):325-34, http://dx.doi.org/10.1016/0022-510X (89) 90119-6.

27. Wild P, Massin N, Lasfargues G, Baudin V, Unlu D, Donati P. Vibrotactile perception thresholds in four non-exposed populations of working age. Ergonomics. 2001;44(6): 649-57, http://dx.doi.org/10.1080/00140130116704.

28. Cholewiak RW, Collinss AA. Vibrotactile localization on the arm: effects of place, space, and age. Percept Psychophys. 2003;65(7):1058-77, http://dx.doi.org/10.3758/ BF031 94834.

29. Deshpande NN, Metter EJ, Ling S, Conwit R, Ferrucci L. Physiological correlates of age-related decline in vibrotactile sensitivity. Neurobiol Aging. 2008;29(5):765-73, http:// dx.doi.org/10.1016/j.neurobiolaging.2006.12.002.
30. Brammer AJ, Piercy JE. Rationale for measuring vibrotactile perception at the fingertips as proposed for standardization in ISO 13091-1. In: Lundstrom R, Lindmark A, editors. Eighth International Conference on Hand-Arm Vibration 9-12 June 1998, Umea, Sweden. Stockholm: National Institute for Working Life; 2000. p. 125-32.

31. Aatola S, Färkkilä M, Pyykkö I, Korhonen O, Starck J. Vibration perception thresholds of forest worker's fingers during temporary obstructed blood circulation. Int Arch Occup Environ Health. 1990;62(6):451-3, http://dx.doi.org/10.1007/ BF00379062.

32. Bovenzi M. Exposure-response relationship in the hand-arm vibration syndrome: An overwiev of current epidemiology research. Int Arch Occup Environ Health. 1998;71:509-19.

This work is available in Open Access model and licensed under a Creative Commons Attribution-NonCommercial 3.0 Poland License - http://creativecommons.org/ licenses/by-nc/3.0/pl/deed.en. 